\title{
Factors associated with unfavorable outcome of tuberculosis treatment in people deprived of liberty: a systematic review
}

Fatores associados ao desfecho desfavorável do tratamento da tuberculose em pessoas privadas de liberdade: revisão sistemática

Factores asociados al resultado desfavorable del tratamiento de la tuberculosis en individuos privados de libertad: revisión sistemática

How to cite this article:

Saita NM, Andrade RLP, Bossonario PA, Bonfim RO, Hino P, Monroe AA. Factors associated with unfavorable outcome of tuberculosis treatment in people deprived of liberty: a systematic review. Rev Esc Enferm USP. 2021;55:e20200583. DOI: https://doi.org/10.1590/1980-220X-REEUSP-2020-0583.

\author{
Nanci Michele Saita ${ }^{1}$ \\ Rubia Laine de Paula Andrade ${ }^{1}$ \\ Pedro Augusto Bossonario ${ }^{1}$ \\ Rafaele Oliveira Bonfim ${ }^{1}$ \\ Paula Hino ${ }^{2}$ \\ Aline Aparecida Monroe ${ }^{1}$ \\ ${ }^{1}$ Universidade de São Paulo, Escola \\ de Enfermagem de Ribeirão Preto, \\ Departamento Materno Infantil e Saúde \\ Pública, Ribeirão Preto, SP, Brazil. \\ ${ }^{2}$ Universidade Federal de São Paulo, Escola \\ Paulista de Enfermagem, Departamento de \\ Saúde Coletiva, São Paulo, SP, Brazil.
}

Corresponding author:

Rubia Laine de Paula Andrade

Avenida dos Bandeirantes, 3900, Campus

Universitário, Bairro Monte Alegre

14040-902 - Ribeirão Preto, SP, Brazil

rubia@eerp.usp.br

\begin{abstract}
Objective: to analyze factors associated with unfavorable outcome of tuberculosis treatment in people deprived of liberty. Method: systematic review, carried out in March 2021 in seven databases, with no delimitation of period of publication. The selection process of publications and data extraction was carried out by two independent reviewers. Results: a total of 1,448 publications was identified and nine were included in the study. Unfavorable outcome was higher among those who were men; had low level of education; were living in a rural area before detention; had longer prison time; received occasional visits; had been transferred between prisons; with no sputum smear microscopy or with a positive result at the diagnosis; with no follow-up sputum smear microscopy, previous history of tuberculosis; having both clinical forms of the disease, HIV/AIDS; alcoholics; smokers; low body weight; and self-administered treatment. Treatment default was associated with young people and death with older people. Conclusion: prison health managers and professionals are expected to establish mechanisms of surveillance and health actions innovation aimed at the population deprived of liberty, making efforts to reduce the unfavorable outcomes of tuberculosis treatment.
\end{abstract}

DESCRIPTORS

Public Health; Tuberculosis; Treatment Outcome; Prisons; Prisoners; Systematic Review. 


\section{INTRODUCTION}

People deprived of liberty (PDL) live in inhumane conditions, with a high number of inmates and no ventilation or sunlight in cells ${ }^{(1)}$. Such conditions increase 28 times the chances of this population becoming ill with tuberculosis (TB), when compared to the general population ${ }^{(2-3)}$.

Tuberculosis represents a public health problem in prisons, as the notification rate is 11 to 81 times higher than in the general population. In Brazil, $7.8 \%$ of notifications of new TB cases are attributed to the prison population ${ }^{(4-5)}$.

Other factors that can contribute to the occurrence of the disease in prisons are related to the infection by the human immunodeficiency virus (HIV) and the difficult access to health services ${ }^{(3)}$. As for HIV, it should be noted that international studies indicate a higher prevalence of infection in the prison environment compared to the general population $^{(6-7)}$. In 2017, among 10 million people who became ill due to TB, 900,000 were living with HIV, and of these, 300,000 died ${ }^{(8)}$.

As for access to health services, according to the Brazilian Policy for Comprehensive Health Care for the Prison Population (PNAISP), the Brazilian system shall be able to offer comprehensive health care for PDL, anchored in the principles and guidelines of the Brazilian Public Health System (SUS). This allows ensuring the ability to diagnose and notify diseases such as TB within prisons, or refer the case to a specialized service in the health care network ${ }^{(9-10)}$.

Among their attributions, prison health units shall offer actions focused on the active case finding, screening of people with HIV, and on timely treatment of TB, contributing to the favorable outcome of cases of the disease $\mathrm{e}^{(10-12)}$.

In spite of that, TB-related mortality and treatment default are high in these settings and have been reported in several places of the world, such that judgment enforcement is expected to make PDL susceptible to TB, and consequently, to death ${ }^{(5,13)}$.

Considering that TB is a public health problem affected by the prison context, in which the occurrence of unfavorable outcomes is significant, this systematic literature review aims to identify and analyze the factors associated with these outcomes of TB treatment in PDL, bearing in mind that such recognition may help in the implementation of prison health policies.

\section{METHOD}

\section{Type OF Study}

This is a systematic review conducted in accordance with the Preferred Reporting Items for Systematic Reviews and Meta-Analyses (PRISMA) ${ }^{(14)}$ and registered in PROSPERO database (CRD42018096148). The registration in PROSPERO underwent two changes: the first contemplated a change in the study population, that is, from people with TB/HIV co-infection to people with TB; in the second update, adjustments were made to the types of studies included in the review and to the way risk of bias was assessed.
The systematic review shall be rigorously developed and is characterized by high-quality evidence, reproducibility, impartiality, and high sensitivity to find all potentially relevant articles ${ }^{(15)}$. It is considered a research modality developed according to the following steps: formulation of the study question; production and registration of an investigation protocol; definition of inclusion and exclusion criteria; search for studies through specific strategies; selection of studies; assessment of methodological quality; data extraction; synthesis of data and assessment of the quality of evidence; publication of results ${ }^{(15)}$.

\section{Data Collection}

Initially, to find the publications, descriptors deriving from the guiding question "What are the factors associated with the unfavorable outcome of TB treatment in PDL?" were identified, with the PEO strategy, proposed by The Joanna Briggs Institute ${ }^{(16)}$ for systematic reviews, which recognizes it as the most adequate to elaborate questions about the exposure effect (Chart 1).

The descriptors in bold type mentioned in Chart 1 are part of the controlled vocabulary found in the Health Sciences Descriptors $(D e C S)$. These descriptors allowed the identification of their synonyms, as well as the corresponding ones in Spanish and English. For the descriptors in English, the Medical Subject Headings (MESH) was also consulted. Then, previous searches were made in the databases to identify the free vocabulary also used when writing publications.

The databases used in the searches were: Excerpta Medica dataBASE (Embase ${ }^{\circledR}$ - https://www.embase. com), Scopus, owned by Elsevier (https://www.scopus. com), MEDLINE or Publisher Medlin (accessed through the PubMed platform - https:// /pubmed.ncbi.nlm.nih. gov/) and Latin American and Caribbean Literature on Health Sciences (LILACS - accessed through the Regional Portal of the Virtual Health Library - https://pesquisa.bvsalud.org/portal/advanced). Finally, the searches performed in the Cumulative Index to Nursing and Allied Health Literature (CINAHL), Academic Search Premier (ASP) and SocINDEX databases were performed simultaneously through the EBSCOhost platform accessed by the CAPES Periodicals website (https://www.periodicos.capes.gov.br), which automatically deletes duplicates found in these databases. In the searches performed in LILACS, vocabulary in Portuguese, English, and Spanish was used. For searches in other databases, the vocabulary in English was used.

The searches were carried out in March 2021, using specific strategies according to each database and the Boolean operators AND and OR (Chart 2). It should be noted

Chart 1 - Elaboration of the study question according to the PEO strategy, Ribeirão Preto, 2021.

\begin{tabular}{|c|c|c|}
\hline Acronym & Definition & Descriptors \\
\hline $\mathbf{P}$ & Patient or Problem & $\begin{array}{c}\text { People deprived of liberty (prisoners) } \\
\text { in prisons }\end{array}$ \\
\hline $\mathbf{E}$ & Exposure & Associated factors \\
\hline $\mathbf{O}$ & Outcome & $\begin{array}{c}\text { Tuberculosis treatment outcome } \\
\text { (unfavorable outcome of cases) }\end{array}$ \\
\hline
\end{tabular}


Chart 2 - Bibliographic search strategies used in the systematic review on the factors associated with the unfavorable outcome of tuberculosis treatment in people deprived of liberty, according to the databases surveyed, Ribeirão Preto, 2021.

\begin{tabular}{|c|c|}
\hline Data base & Search strategy \\
\hline Embase $^{\circledast}$ & 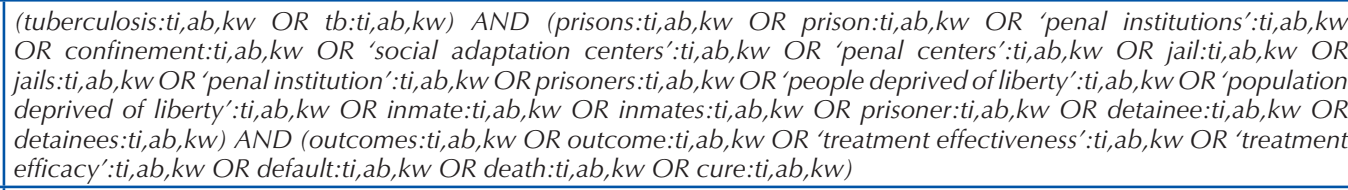 \\
\hline Scopus & $\begin{array}{l}\text { TITLE-ABS-KEY(tuberculosis OR tb OR "Koch Disease") AND TITLE-ABS-KEY(prisons OR prison OR "Penal institutions" } \\
\text { OR confinement OR "Social Adaptation Centers" OR "Penal Centers" OR jail OR jails OR "Penal Institution" OR } \\
\text { prisoners OR "People Deprived of Liberty" OR "Population Deprived of Liberty" OR inmate OR inmates OR prisoner } \\
\text { OR detainee OR detainees) AND TITLE-ABS-KEY(outcomes OR outcome OR "Treatment Effectiveness" OR "Treatment } \\
\text { Efficacy" OR default OR death OR cure) }\end{array}$ \\
\hline MEDLINE & $\begin{array}{l}\text { ((Tuberculosis[Title/Abstract] OR TB[Title/Abstract] OR "Koch Disease"[Title/Abstract]) AND (Prisons[Title/Abstract] } \\
\text { OR Prison[Title/Abstract] OR "Penal institutions"[Title/Abstract] OR confinement[Title/Abstract] OR "Social } \\
\text { Adaptation Centers"[Title/Abstract] OR "Penal Centers"[Title/Abstract] OR Jail[Title/Abstract] OR /ails[Title/Abstract] } \\
\text { OR "Penal Institution"[Title/Abstract] OR Prisoners[Title/Abstract] OR "People Deprived of Liberty"[Title/Abstract]] } \\
\text { OR "Population Deprived of Liberty"[Title/Abstract] OR Inmate[Title/Abstract] OR Inmates[Title/Abstract] OR } \\
\text { Prisoner[Title/Abstract] OR Detainee[Title/Abstract] OR Detainees[Title/Abstract])) AND (Outcomes[Title/Abstract] } \\
\text { OR Outcome[Title/Abstract] OR "Treatment Effectiveness"[Title/Abstract] OR "Treatment Efficacy"[Title/Abstract] OR } \\
\text { Default[Title/Abstract] OR Death[Title/Abstract] OR Cure[Title/Abstract]) }\end{array}$ \\
\hline LILACS* & 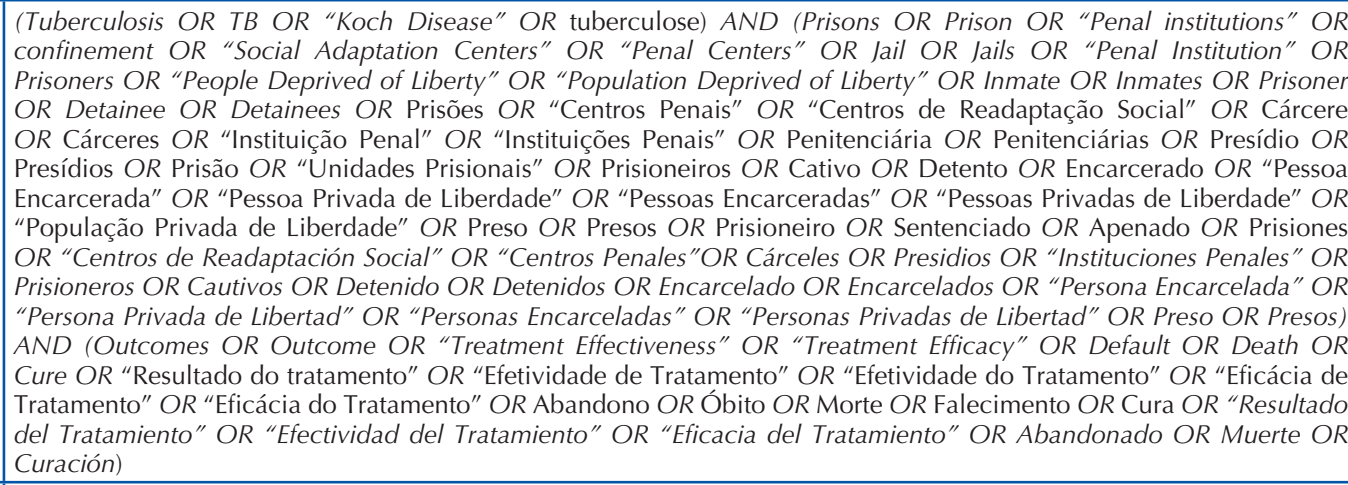 \\
\hline $\begin{array}{c}\text { Academic Search Premier } \\
\text { CINAHL } \\
\text { SocINDEX }\end{array}$ & $\begin{array}{l}\text { AB (Tuberculosis OR TB OR "Koch Disease") AND AB (Prisons OR Prison OR "Penal institutions" OR confinement } \\
\text { OR "Social Adaptation Centers" OR "Penal Centers" OR Jail OR Jails OR "Penal Institution" OR Prisoners OR "People } \\
\text { Deprived of Liberty" OR "Population Deprived of Liberty" OR Inmate OR Inmates OR Prisoner OR Detainee OR } \\
\text { Detainees) AND AB (Outcomes OR Outcome OR "Treatment Effectiveness" OR "Treatment Efficacy" OR Default OR } \\
\text { Death OR Cure) }\end{array}$ \\
\hline
\end{tabular}

TITLE-ABS-KEY and ti, ab, $k w$ refer to the search performed for words in the title, abstract and keywords; Title/Abstract refers to the search performed for words in the abstract; $A B$ refers to the search performed for words in the abstract.

*In the Regional Portal of the Virtual Health Library, the title, abstract, and subject words were searched and the LILACS filter was used in the consulted databases.

that the Boolean operator OR was used between words in the same group ("word" OR "word") and AND was used between the set of words from different groups ("set of words from group $p_{1}$ AND "set of words from group 2 " AND "set of words from group” $\left.{ }_{3}\right)$.

\section{InClusion ANd EXCLUSION CRITERIA}

The bibliographic search did not use year of publication limit aiming at exhausting the sources of information on the topic in question. Search results were exported to Qatar Computing Research Institute's Rayyan QCRI online systematic review application ${ }^{(17)}$. After export, duplicated publications were excluded, and the remaining had their abstracts and titles read by two independent reviewers. For the selection of publications, the following eligibility criteria were defined: primary studies testing the hypothesis that there are factors associated with the TB treatment outcome in the prison system; research aimed at the specific study of PDL with TB; studies addressing factors associated with favorable/unfavorable outcome or non-cure, or death, or treatment default. Thus, studies analyzing the general population together with PDL and those that specifically studied factors associated with treatment failure, or transference, or uninformed outcomes were excluded. After reading the titles and abstracts, the selected publications were submitted to full reading, which allowed identifying the articles that were really relevant to the review.

\section{Data Analysis}

The articles included underwent narrative synthesis following data extraction, performed by one reviewer and checked by another. For this, a specific instrument based on Ursi ${ }^{(18)}$ was used, which presented the following variables: article title, journal name, authors, place studied (country), language, year of publication, type of study, objective, studied population, sample calculation, sampling, characteristics of the studied population, data collection source, dependent variable, independent variables, statistical treatment, main results, and conclusions. The results were presented in demonstrative charts and complemented by the analysis made in the discussion. 
The articles' methodological quality was assessed through the use of specific instruments proposed by The Joanna Briggs Institute $(\mathrm{JBI})^{(19)}$. In this case, the instrument that assesses cohort, case-control-retrospective studies, and another that assesses cross-sectional studies were used, allowing the indication of the number of items adequately addressed in the studies, according to the number of items provided by the instruments ( 11 items provided for cohort studies - however, two items did not apply to these studies because they were retrospective cohorts; ten items for casecontrol studies; and eight items for cross-sectional studies). Limitations in the articles were also sought to complement this assessment. No study was excluded due to the assessment of methodological quality.

\section{RESULTS}

The search allowed the identification of 1,448 scientific productions, of which 470 publications were excluded because they were duplicates and 947 after their titles and abstracts. Thus, 31 publications were considered eligible for full reading, of which 22 were excluded, with nine articles remaining in the review (Figure 1).

The articles included in this review ${ }^{(20-28)}$ were published in English ${ }^{(21,23-28)}$, Spanish ${ }^{(22)}$ and one in two versions Portuguese and English ${ }^{(20)}$. Five studies are from the African continent $^{(21,24-26,28)}$, three from South America ${ }^{(20,22,27)}$, and one from the Asian continent ${ }^{(23)}$. Regarding the year of publication, the articles were published in $2013^{(27-28)}, 2014^{(26)}$, $2018^{(24,25)}, 2019^{(22-23)}$, and $2020^{(20-21)}$. The articles included worked with population, and no sample calculation was performed or presented. However, two studies ${ }^{(20,22)}$ showed

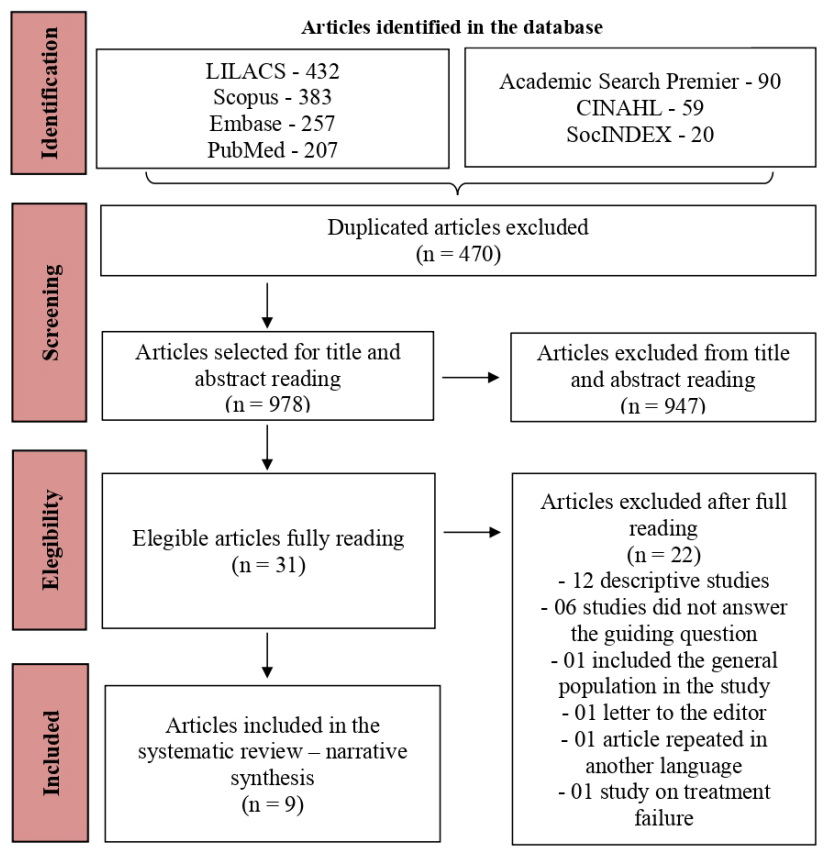

Figure 1 - Flowchart of articles identification and inclusion in the systematic review on factors associated with the unfavorable outcome of tuberculosis treatment in people deprived of liberty, Ribeirão Preto, 2021.

Source: Adapted from Moher D et al. (2009) ${ }^{(14)}$. considerable loss regarding the study population due to ignored/blank data in the information systems.

As for the methodological quality of the productions, the main limitations of the studies were the collection of secondary data in all the articles included, whose exposure and outcome measures may not be reliable ${ }^{(20-28)}$, and the failure to identify confounding variables ${ }^{(21-24,25-27)}$ and strategies to deal with them ${ }^{(21-23-28)}$. Two studies presented unreliable analysis, since it was not possible to identify the reference variable of some analyses ${ }^{(23,28)}$ and some odds ratio values were not aligned with the confidence interval ${ }^{(28)}$. In addition, the occurrence of mistakes in the design of the types of study in two articles included shall be highlighted ${ }^{(22,25)}$.

Data related to the articles included in this review are presented in Chart 3.

Regarding the results of this systematic review, the articles presented different approaches to the object of interest, sometimes considering an unfavorable outcome such as death, loss to follow-up, and unidentified outcome all together ${ }^{(21)}$; or evaluating treatment default, failure, and death together ${ }^{(22,24)}$; or abandonment, treatment failure, and transfer together ${ }^{(23)}$; failure, death, transfer, and unidentified outcome together ${ }^{(25)}$; and sometimes failure, recurrence and death together ${ }^{(28)}$. In addition, three other studies assessed default ${ }^{(20,26-27)}$ and death from $\mathrm{TB}^{(27)}$ and from other causes ${ }^{(27)}$, separately. The different approaches made a quantitative synthesis of information impossible. In the narrative synthesis of the factors associated with the outcome of TB cases in PDL, the findings were grouped according to sociodemographic, imprisonment, clinical, and treatment characteristics (Chart 4).

\section{DISCUSSION}

Among the sociodemographic characteristics, the risk of an unfavorable outcome of TB treatment in the prison system in relation to age group did not show a pattern in the articles studied. In two of them, the risk was higher in young adults ${ }^{(23,28)}$, while in another study it was higher in the older population $^{(21)}$. However, when evaluated separately, treatment default was higher in people under 43 years old ${ }^{(27)}$, while death was higher in people aged $\geq 30$ years old ${ }^{(27)}$. Thus, it seems that TB treatment default in the prison unit is more common among young people, consistent with a study showing that older individuals with the disease were more concerned with self-care and cared more for their health ${ }^{(29)}$. Despite this, everything indicates that older people are more likely to die, and this is due to the overlapping of comorbidities in this population and greater toxicity of antituberculous drugs in these individuals ${ }^{(30)}$.

Evidence of an association between being men and cases that did not progress to cure was found in one of the studies found ${ }^{(28)}$. The other studies did not mention this aspect, since most of ${ }^{(20,23-24,26,28)}$ or all ${ }^{(21,22,25,27)}$ populations studied were male. In this regard, the need to carry out research on the subject in question, aimed at the female population and the fragility of self-care of the male population in the prison system, who seeks health services only in acute situations and abstains from healthcare to culturally transfer an image of strength ${ }^{(31-32)}$. 
Chart 3 - Description of the articles included in the systematic review on factors associated with the unfavorable outcome of tuberculosis treatment in people deprived of liberty, Ribeirão Preto, 2021.

\begin{tabular}{|c|c|c|c|c|c|}
\hline $\begin{array}{l}\text { Authors / Journal / Year } \\
\text { of publication / Country }\end{array}$ & Study design & Objective & Total $(\mathbf{N})$ & Main results & $\begin{array}{c}\text { Methodological } \\
\text { quality } \\
\text { assessment }\end{array}$ \\
\hline $\begin{array}{l}\text { Alves et al. }{ }^{(20)} / \\
\text { Revista Brasileira de } \\
\text { Epidemiologia / } 2020 \text { / } \\
\text { Brazil }\end{array}$ & Retrospective & $\begin{array}{l}\text { To investigate the factors } \\
\text { associated with cure and } \\
\text { default outcomes in PDL } \\
\text { affected by TB. }\end{array}$ & $\begin{array}{l}614 \mathrm{PDL} \geq 18 \text { years } \\
\text { (93.8\% were men })\end{array}$ & $\begin{array}{l}\text { Increased risk of treatment default } \\
\text { (multivariate analysis): } \\
\text { - individuals with AIDS } \\
\quad(\mathrm{aRR}=2.00 ; \mathrm{Cl} 1.08-3.70 ; \\
\quad \mathrm{p}=0.028) ; \\
\text { - no follow-up sputum smear } \\
\quad \text { microscopy }(\mathrm{aRR}=5.21 ; \\
\quad \mathrm{Cl} 2.16-12.58 ; \mathrm{p}<0.001)\end{array}$ & $7 / 9$ \\
\hline $\begin{array}{l}\text { Mandizvidza et al. } \text {. }^{(1)} \text { / } \\
\text { Tuberculosis Research } \\
\text { and Treatment / } 2020 \text { / } \\
\text { Zimbabwe }\end{array}$ & $\begin{array}{l}\text { Retrospective } \\
\text { cohort }\end{array}$ & $\begin{array}{l}\text { To measure TB } \\
\text { prevalence and } \\
\text { treatment outcomes } \\
\text { among inmates in } \\
\text { two large prisons in } \\
\text { Zimbabwe. }\end{array}$ & $\begin{array}{l}280 \text { men deprived } \\
\text { of liberty with TB } \\
\text { diagnosis } \geq 18 \text { years }\end{array}$ & $\begin{array}{l}\text { Increased risk of unfavorable } \\
\text { outcome (multivariate analysis): } \\
\text { - individuals aged } \geq 60 \text { years } \\
\quad(\text { aRR }=2.80 ; \mathrm{Cl} 1.10-6.90 ; \\
\mathrm{p}=0.030) ; \\
\text { - individuals with no record } \\
\text { of diagnostic sputum } \\
\text { smear microscopy results } \\
(\text { aRR }=1.99 ; \mathrm{Cl} 1.04-3.81 ; \\
\mathrm{p}=0.038)\end{array}$ & $5 / 9$ \\
\hline $\begin{array}{l}\text { Chong; Marin; Pérez } z^{(22)} \text { / } \\
\text { Revista Panamericana de } \\
\text { Salud Publica / } 2019 \text { / } \\
\text { Ecuador }\end{array}$ & $\begin{array}{l}\text { Cross-sectional, } \\
\text { descriptive }\end{array}$ & $\begin{array}{l}\text { To assess the control } \\
\text { of pulmonary TB in a } \\
\text { detention center and } \\
\text { identify risk factors } \\
\text { associated with } \\
\text { unsuccessful treatment } \\
\text { of the disease. }\end{array}$ & $\begin{array}{l}59,846 \text { men deprived } \\
\text { of liberty }>15 \text { years, } \\
\text { of which } 326 \text { were } \\
\text { diagnosed with TB } \\
\text { and } 184 \text { had a record } \\
\text { of treatment outcome }\end{array}$ & $\begin{array}{l}\text { Increased risk of unsuccessful } \\
\text { treatment (multivariate analysis): } \\
\text { - coinfection with HIV } \\
\quad(\mathrm{aRR}=1.66 ; \mathrm{Cl} 1.33-2.07) .\end{array}$ & $4 / 8$ \\
\hline $\begin{array}{l}\text { Khan et al. }{ }^{(23)} / \\
\text { Infectious Diseases } \\
\text { in Clinical Practice / } \\
2019 \text { / Malaysia }\end{array}$ & Cross-sectional & $\begin{array}{l}\text { To analyze the scenario } \\
\text { related to the number } \\
\text { of prisoners with TB } \\
\text { in prisons in four } \\
\text { Malaysian states and to } \\
\text { identify factors affecting } \\
\text { treatment outcomes. }\end{array}$ & $\begin{array}{l}405 \text { PDL (98.0\% were } \\
\text { men) }\end{array}$ & $\begin{array}{l}\text { In the multivariate analysis, } \\
\text { no variable was associated with } \\
\text { unsuccessful treatment. } \\
\text { Protection factor against } \\
\text { unsuccessful treatment } \\
\text { (multivariate analysis): } \\
\text { - age group }>35 \text { years } \\
\text { (OR } 0.60 ; p=0.02 \text { ). }\end{array}$ & $4 / 8$ \\
\hline $\begin{array}{l}\text { Adane et al. } .^{(24)} / \text { BMC } \\
\text { Pulmonary Medicine / } \\
2018 \text { / Ethiopia }\end{array}$ & Retrospective & $\begin{array}{l}\text { To assess the outcome } \\
\text { of TB treatment and } \\
\text { identify risk factors for } \\
\text { unsuccessful outcomes } \\
\text { in prisons in northern } \\
\text { Ethiopia. }\end{array}$ & $\begin{array}{l}496 \mathrm{PDL} \geq 15 \text { years } \\
(96.8 \% \text { were } \text { men })\end{array}$ & $\begin{array}{l}\text { Factors associated with } \\
\text { unfavorable treatment outcomes } \\
\text { (multivariate analysis): } \\
\text { - retreatment cases (OR 4.68; } \\
\quad \mathrm{CI} 1.02-21.4 \text { ) compared to } \\
\text { new cases. } \\
\text { When deaths were analyzed } \\
\text { separately, the chance of dying in } \\
\text { patients with body weight }<50 \mathrm{~kg} \\
\text { at the beginning of treatment } \\
\text { was } 8.4 \text { times higher }(\mathrm{OR}=8.39 ; \\
\mathrm{Cl} 1.01-70.34 \text { ) compared to the } \\
\text { other group with weight } \geq 50 \mathrm{~kg} \text {. }\end{array}$ & $7 / 10$ \\
\hline $\begin{array}{l}\text { Berihun et al. }{ }^{(25)} / \\
\text { Ethiopian Journal of } \\
\text { Health Sciences / } \\
2018 \text { / Ethiopia }\end{array}$ & $\begin{array}{l}\text { Cross-sectional, } \\
\text { retrospective }\end{array}$ & $\begin{array}{l}\text { To assess the prevalence } \\
\text { of TB and treatment } \\
\text { outcomes of TB patients } \\
\text { in inmates at Debre } \\
\text { Berhan Prison in Semien } \\
\text { Shewa, Ethiopia. }\end{array}$ & $\begin{array}{l}162 \text { men deprived of } \\
\text { liberty from } 15 \text { to } 56 \\
\text { years old (mean age } \\
30.2 \text { (sd 9.77) years } \\
\text { old }\end{array}$ & $\begin{array}{l}\text { Factors associated with successful } \\
\text { treatment outcomes (multivariate } \\
\text { analysis): } \\
\text { - residence in an urban area } \\
\quad \text { before arrest (aOR }=3.59 ; \\
\quad \text { Cl } 1.44-8.93) ; \\
\text { - duration of detention } \\
\quad \text { two years ( } \neq \text { aOR }=3.67 ; \\
\quad \text { Cl } 1.53-8.78 \text { compared to } \\
\text { > two years); } \\
\text { - No previous history of TB } \\
\left.\text { (aOR }=1.52 ;{ }^{+} \mathrm{Cl} 1.03-23.78\right) .\end{array}$ & $7 / 10$ \\
\hline $\begin{array}{l}\text { Schwitters et al.(26) / } \\
\text { International Journal } \\
\text { of Tuberculosis and } \\
\text { Lung Disease / } 2014 \text { / } \\
\text { Uganda }\end{array}$ & Retrospective & $\begin{array}{l}\text { To determine TB } \\
\text { incidence among } \\
\text { Ugandan prisoners and } \\
\text { analyze TB treatment } \\
\text { outcomes and risk } \\
\text { factors for standard } \\
\text { of care. }\end{array}$ & $\begin{array}{l}469 \mathrm{PDL} \geq 18 \text { years } \\
\text { (98.1\% were men) }\end{array}$ & $\begin{array}{l}\text { Factor associated with treatment } \\
\text { default (multivariate analysis): } \\
\text { - transfer from prison unit } \\
\quad(\mathrm{aOR}=8.36 \text {; } \mathrm{Cl} 4.69-14.91) .\end{array}$ & $7 / 10$ \\
\hline
\end{tabular}




\section{...continuation}

\begin{tabular}{|c|c|c|c|c|c|}
\hline $\begin{array}{l}\text { Authors / Journal / Year } \\
\text { of publication / Country }\end{array}$ & Study design & Objective & Total (N) & Main results & $\begin{array}{c}\text { Methodological } \\
\text { quality } \\
\text { assessment } \\
\end{array}$ \\
\hline $\begin{array}{l}\text { Macedo et al.(27)/ } \\
\text { International Journal of } \\
\text { Tuberculosis and Lung } \\
\text { Disease / } 2013 \text { / Brazil }\end{array}$ & Retrospective & $\begin{array}{l}\text { To analyze the clinical } \\
\text { and epidemiological } \\
\text { characteristics } \\
\text { associated with the } \\
\text { outcome of TB treatment } \\
\text { in the Brazilian prison } \\
\text { population. }\end{array}$ & $\begin{array}{l}14,874 \text { men deprived } \\
\text { of liberty } \geq 18 \text { years }\end{array}$ & 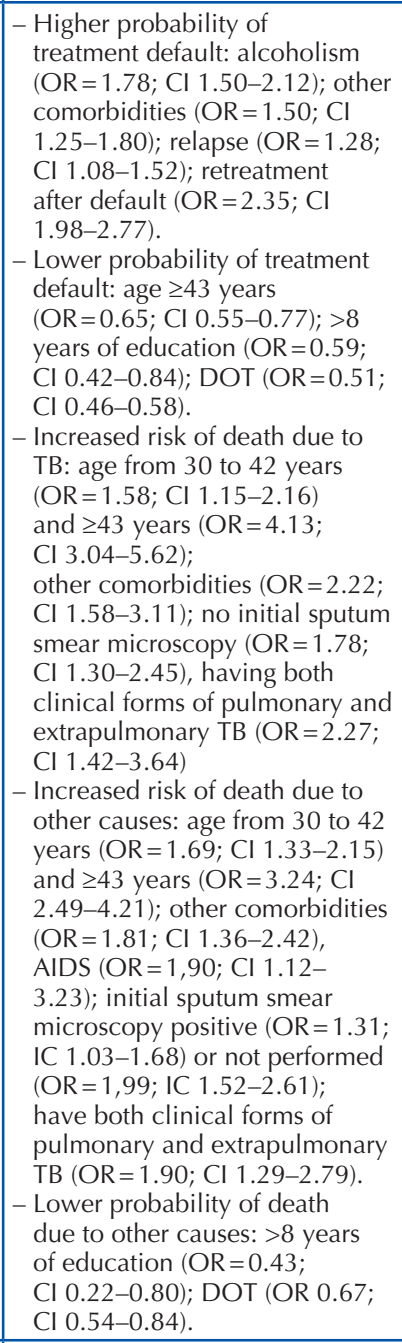 & $7 / 10$ \\
\hline $\begin{array}{l}\text { Mnisi et al. }{ }^{(28)} \text { / } \\
\text { Southern African } \\
\text { Journal of Epidemiology } \\
\text { and Infection / } 2013 \text { / } \\
\text { South Africa }\end{array}$ & Retrospective & $\begin{array}{l}\text { To explore the } \\
\text { factors associated } \\
\text { with pulmonary TB } \\
\text { treatment outcomes in } \\
\text { Potchefstroom Prison. }\end{array}$ & $\begin{array}{l}202 \mathrm{PDL} \geq 21 \text { years } \\
\text { (98.0\% were men) }\end{array}$ & 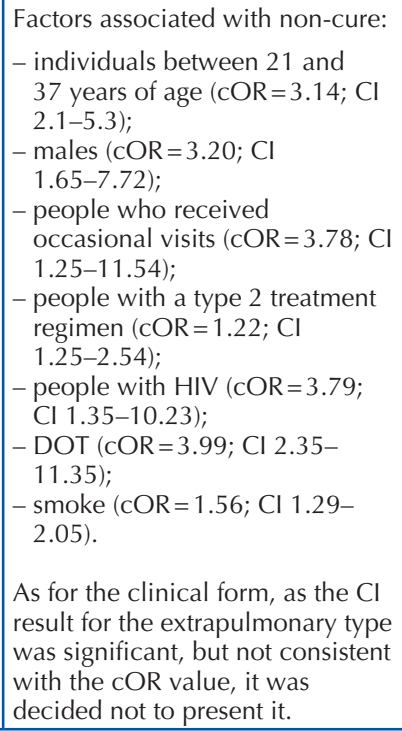 & $7 / 10$ \\
\hline
\end{tabular}

aOR - adjusted odds ratio; COR - crude odds ratio; aRR - adjusted relative risk; $\mathrm{Cl}$ - confidence interval (all were 95\%); OR - odds ratio; PDL - people deprived of liberty; DOT - directly observed treatment; TB - tuberculosis. 
Chart 4 - Description of factors associated with the unfavorable outcome of tuberculosis treatment in people deprived of liberty, according to the type of outcome studied and sociodemographic, imprisonment, clinical, and treatment characteristics, Ribeirão Preto, 2021.

\begin{tabular}{|c|c|c|c|c|}
\hline \multirow[b]{2}{*}{ Characteristics } & \multicolumn{4}{|c|}{ Associated factors } \\
\hline & $\begin{array}{l}\text { Unfavorable outcome / unsuccessful } \\
\text { treatment / no cure }\end{array}$ & Treatment default & Death from TB & Death from other causes \\
\hline Sociodemographic & $\begin{array}{c}\text { Age groups from } 21 \text { to } 37 \text { yearss } 288 \text {, } \\
\leq 35 \text { years }{ }^{(23)} \text { and } \geq 60 \text { years }{ }^{(21)} ; \\
\text { Males }^{(28) ;} \text {; } \\
\text { To live in the rural area before } \\
\text { imprisonment }{ }^{25)} \text {. }\end{array}$ & $\begin{array}{c}\text { Age group }<43 \text { years }{ }^{(27)} \\
\text { Level of education } \leq 8 \\
\text { years }\end{array}$ & $\begin{array}{l}\text { Age group from } 30 \text { to } 42 \\
\text { years and } \geq 43 \text { years }^{(27)} \text {. }\end{array}$ & $\begin{array}{l}\text { Age group from } 30 \text { a } \\
42 \text { years and } \geq 43 \text { years }{ }^{(27)} ; \\
\text { Level of education } \\
\leq 8 \text { years }{ }^{(27)} \text {. }\end{array}$ \\
\hline Imprisonment & $\begin{array}{c}\text { Time of imprisonment }>2 \text { years( }{ }^{(25)} \\
\text { Receiving occasional visits }\end{array}$ & $\begin{array}{c}\text { Transfer to other prison } \\
\text { units }^{(26)} \text {. }\end{array}$ & & \\
\hline Medical & $\begin{array}{c}\text { Individual without diagnostic sputum } \\
\text { smear microscopy results } 2(1) ; \\
\text { People with a previous history of } \\
\mathrm{TB}^{(24,25)} ; \\
\mathrm{HIV}^{(22,28)} ; \\
\text { Smoking }{ }^{(28)}\end{array}$ & $\begin{array}{l}\text { AIDS }^{(20)} ; \\
\text { Alcohol use } \\
\text { Other comorbidities } \\
\text { People with a previous } \\
\text { history of TB }{ }^{(27)} ;\end{array}$ & $\begin{array}{l}\text { Body weight }<50 \mathrm{~kg}^{(24)} ; \\
\text { Other comorbidities } \\
\text { No diagnostic sputum } \text { smear }^{(27)} \\
\text { microscopy performed } \\
\text { Pulmonary }+ \\
\text { extrapulmonary } \mathrm{TB}^{(27)} \text {; } \\
\text { HIV negative }{ }^{(27)} \text {. }\end{array}$ & $\begin{array}{c}\text { Other comorbidities }{ }^{(27)} \text {; } \\
\text { AIDS }{ }^{(27)} ; \\
\text { Diagnostic sputum smear } \\
\text { microscopy not performed } \\
\text { or positive } \\
\text { Pulmonary }+ \\
\text { extrapulmonary TB } \\
\text { T27); }\end{array}$ \\
\hline Treatment & $\mathrm{DOT}^{(28)}$. & $\begin{array}{l}\text { No follow-up sputum } \\
\text { smear microscopy } \\
\text { performed } \\
\text { Self-; } ; \\
\text { treadministered } \\
\text { treatment }^{27)} \text {. }\end{array}$ & & $\begin{array}{l}\text { Self-administered } \\
\text { treatment }{ }^{27} \text {. }\end{array}$ \\
\hline
\end{tabular}

TB - tuberculosis; DOT - directly observed treatment.

Regarding education, a survey showed that individuals with more than eight years of education were less likely to discontinue treatment and die from other causes ${ }^{(27)}$. Another study shows that the lower level of knowledge about TB was associated with people with low level of education ${ }^{(33)}$, who are less concerned with self-care ${ }^{(29)}$ and, therefore, discontinue treatment and are subject to a higher risk of death. Thus, it is worth emphasizing the importance of health education actions aimed at these individuals, with a view to increasing the level of knowledge about the disease and its treatment, as well as the need to maintain such treatment even after symptoms improve ${ }^{(34)}$.

Living in an urban area before imprisonment showed a greater chance of success in treatment compared to residents of rural areas ${ }^{(25)}$. A study in the general population in Rio de Janeiro also showed that people with TB living in rural areas were associated with unfavorable outcomes when compared to those living in urban areas ${ }^{(35)}$. This result could be explained with the hypothesis that individuals living in rural areas have less access to education and healthcare ${ }^{(36)}$, leading to an important deficit of information about the disease and its treatment, reinforcing the importance to carry out the actions of health education mentioned above to increase the chances of cure among the cases affected.

As for the characteristics of imprisonment, people with a shorter time of incarceration had a greater chance of treatment success ${ }^{(25)}$, and it is difficult to find an explanation for this occurrence. It is believed that these people in early imprisonment received visits more frequently, which may have led to a greater chance of cure compared to people who received occasional visits, as this characteristic is also associated with the occurrence of unfavorable outcomes ${ }^{(28)}$. Receiving visits seems to be an important motivational aspect offered by family and friends with regard to therapeutic adherence, since such support is pointed out as very important for emotional support and continuity of treatment, showing the importance of words of comfort and affection and the feeling of feeling loved during the period of illness ${ }^{(37)}$.

Evidence was also found that cases of transfer to other prison units were more likely to result in treatment discontinuation $^{(26)}$, that is, PDL with TB lost the follow-up of their disease when they were transferred, showing that there was no coordination of care nor a care transition plan from the prison unit to the community, which presupposes the need for referral and dialogue with care services for the continuity of care ${ }^{(38)}$. Thus, providing a care transition plan for sick people on release, with appropriate referrals for community care, has a positive impact on post-release outcomes as it provides a roadmap for those returning to the community. If the individual is successfully engaged and maintained in care, this can lead to better health outcomes, not only for the individual, but also for the community ${ }^{(39)}$.

Regarding clinical characteristics, people with a previous history of $\mathrm{TB}$ were more likely to have an unfavorable outcome $^{(24,25)}$ and treatment discontinuation ${ }^{(27)}$. In a study conducted in Peru, the authors identified that patients who had previously discontinued treatment had an increased risk not only of abandoning their current treatment, but also of dying ${ }^{(40)}$. Previously treated patients should have additional support at the start of a new treatment to emphasize the importance of adherence and completion of the process. Before starting a new treatment, cases of restart after discontinuation require special attention to the issues contributing to the previous abandonment to avoid serious outcomes such as death ${ }^{(40)}$.

Another result found concerns the association between an unfavorable outcome and individuals who did not undergo diagnostic sputum smear microscopy ${ }^{(27)}$ or who did not present a record of its results ${ }^{(21)}$. These cases may 
have been diagnosed by sputum culture, or, more recently, by rapid molecular tests or clinical diagnosis, which can be supported with the help of radiological images.

These results also show the importance of performing sputum smear microscopy or rapid molecular tests as methods that can contribute to the identification of cases with potential risk for an unfavorable outcome, since another study showed an association between positive TB cases and death from other causes ${ }^{(27)}$. In this study, among these causes of death, a large part refers to HIV infection and $\operatorname{AIDS}^{(27)}$, revealing that among these people, systematic monitoring of cases is essential to identify their severity and progression, especially if at the beginning of treatment they had a positive sputum smear microscopy result.

As for the clinical form of TB, the concomitant pulmonary and extrapulmonary forms increased the chance of death from TB and other causes ${ }^{(27)}$. It is known that the occurrence of extrapulmonary TB is more frequent among immunocompromised people, living or not with HIV/AIDS ${ }^{(41)}$. Thus, the immunological status of individuals affected by both forms of TB shall be evaluated and treated to contribute to the treatment results.

Additionally, it should be noted that HIV infection is associated with a higher occurrence of unfavorable outcomes $^{(22,28)}$ and treatment default ${ }^{(20)}$. Among the possible explanations for this discontinuation, the overlapping of treatments for both diseases is highlighted, which results in adverse events and greater difficulty of treatments compliance ${ }^{(42)}$. Furthermore, as for HIV/AIDS being associated with unfavorable outcomes, the difficulties and delay in the diagnosis of pulmonary TB in individuals with co-infection due to the paucibacillary characteristic of the disease's manifestation in this population ${ }^{(43)}$ shall be highlighted. There are also difficulties in diagnosing extrapulmonary TB in the prison environment, as diagnostic technologies that go beyond the scope of actions offered by prison health units are required, as well as articulation with health services outside the prison system for this diagnosis ${ }^{(44)}$.

The chance of dying from TB was 8.4 times greater in those weighing less than $50 \mathrm{~kg}^{(24)}$, corroborating studies carried out in Ethiopia ${ }^{(45)}$, whose evidence showed that body weight at the beginning of treatment is a significant predictor of the number of deaths. Thus, the death of TB patients can be attributed to the severity of the disease, which resulted in considerable weight loss, or to a precarious previous nutritional status ${ }^{(46)}$.

Such nutritional status can also be affected by imprisonment conditions ${ }^{(47,48)}$ and by other comorbidities, such as smoking and alcoholism, which were also associated with cases of no TB cure in the prison system ${ }^{(27-28)}$. As for smoking, a systematic review presented studies demonstrating the association between tobacco consumption and the increased possibility of unfavorable outcomes among individuals with $\mathrm{TB}^{(49)}$, which is explained by the fact that smokers are largely associated with greater severity of lung disease as they have more severe cavitary lesions ${ }^{(50)}$ and a delay in the final sputum culture conversion ${ }^{(50,51)}$. Thus, the need to implement the Tobacco Control Program in Brazil is highlighted, aiming at the reduction of prevalence of smokers and, consequently, the morbidity and mortality related to the consumption of tobacco derivatives in the country.

A meta-analysis published in 2020 on the impact of alcoholism on the treatment outcome indicated that there is evidence of an association between alcohol abuse and unfavorable TB treatment outcomes, with interventions aimed at reducing alcohol consumption ${ }^{(52)}$ being recommended. In addition, this result leads to reflections on the challenges regarding the entry and circulation of these products in the prison system, which can often be used as a way to deal with the stress and anxiety caused by incarceration conditions ${ }^{(47,48)}$ which, predominantly, are precarious throughout the world. Thus, the early diagnosis of TB combined with guidelines related to low consumption of alcohol and tobacco, as well as the correct intake of medications, can contribute to more favorable outcomes.

Regarding the treatment variables, evidence of an association between treatment default and no performance of follow-up sputum smear microscopy was found ${ }^{(20)}$. This shows a deficiency of the health units in the cases follow-up, which should prioritize the monthly examination to monitor the patient's bacillary load during their treatment in the incarceration environment, as it allows evaluating the presence of bacilli ${ }^{(42)}$ and, consequently, the therapeutic success or drug resistance of the basic regimen.

Directly observed treatment (DOT) is widely recommended and used with the aim of reducing default and death rates and, thus, acting to control the disease $\mathrm{e}^{(53)}$. In prisons, it is assumed that it is easier to perform DOT and monitor the progress of patients ${ }^{(54)}$. One of the studies found in this review showed that individuals under DOT had a lower risk of abandoning TB treatment and dying from other causes ${ }^{(27)}$.

Although the prison unit is a favorable environment for DOT, it is worth reflecting on the difficulties involved in complying with the proposal, namely: occupation above its capacity and with no adequate professional sizing ${ }^{(55-56)}$; supremacy of actions aimed at the security/surveillance of inmates and prison professionals to the detriment of actions aimed at health, which prevents the daily attendance of inmates in prison health units for such supervision and limits the access of healthcare professionals to cells and pavilions ${ }^{(55,57)}$; penitentiary health agents participate in the regulation of access to health actions without adequate knowledge to do so ${ }^{(58)}$.

Complementing the results on DOT, another study showed an association between this treatment modality and a greater chance of non-cure ${ }^{(28)}$. It should be noted that the quality of the information in this last study is questionable due to methodological inconsistencies found in the presentation of its results, namely: some odds ratio values were not aligned with the confidence interval and it was not possible to identify the reference variable of some analyses.

The limitation of the study is the non-evaluation of the evidence quality of this systematic review, as well as the possible non-inclusion of relevant studies indexed in databases not researched in the study; in addition, there is no inclusion of gray literature, which would allow for the identification of other topics/relevant points on the factors associated with the unfavorable outcome of TB cases. 


\section{CONCLUSION}

The study that there is a small number of articles assessing the factors associated with the treatment outcome, even in the face of a broad search for studies in the databases, using controlled and free vocabularies and without limitation of time or language of publication. This result shows that the subject is little explored in the peer-reviewed scientific literature, following the invisibility of PDL, especially while a high number of studies on the subject directed at the general population are identified.

In spite of this, the articles included allowed a synthesis of knowledge on the topic in question, as well as the gathering of factors associated with the unfavorable outcome of TB treatment in prisons in a single study, namely: male sex, low level of education, residence in a rural area before imprisonment, longer imprisonment, receiving occasional visits, transfer between prisons, individuals with no diagnostic sputum smear microscopy result or with a positive result, previous history of TB, HIV/AIDS, having both clinical forms of TB (pulmonary + extrapulmonary), alcoholism, smoking, other comorbidities, low body weight, no follow-up sputum smear microscopy, and no DOT. As for age, it seems that treatment default occurs more in young people and death in older people.

Therefore, the study contributes with elements for health professionals and other social actors to turn their eyes to people with TB in prison health units and make efforts to reduce unfavorable outcomes in this population, according to their characteristics. Practices shall be implemented for the timely diagnosis of cases (with the offer of sputum smear microscopy or rapid molecular testing), clinical management (with the offer of follow-up sputum smear microscopy, actions for the nutritional improvement of patients and harm reduction strategies from alcohol use and drugs), monitoring adherence to treatment (with the offer of DOT) and care transition plans for individuals transferring to other prisons or in a situation of release.

\section{RESUMO}

Objetivo: analisar os fatores associados ao desfecho desfavorável do tratamento da tuberculose em pessoas privadas de liberdade. Método: revisão sistemática, cuja busca foi realizada em março de 2021 em sete bases de dados, sem delimitação de período de publicação. O processo de seleção das publicações e extração de dados foi realizado por dois revisores independentes. Resultados: identificaram-se 1.448 publicações, das quais nove foram incluídas no estudo. Desfecho desfavorável foi maior entre sexo masculino, baixa escolaridade, residente em área rural antes da detenção, maior tempo de aprisionamento, visitas ocasionais, transferência entre unidades prisionais, indivíduos sem baciloscopia ou com resultado positivo no diagnóstico, sem baciloscopia de acompanhamento, história prévia de tuberculose, ter ambas as formas clínicas da doença, HIV/aids, alcoolismo, tabagismo, baixo peso corporal e tratamento autoadministrado. $\mathrm{O}$ abandono do tratamento esteve associado a pessoas jovens e o óbito, a pessoas mais velhas. Conclusão: espera-se que os gestores e profissionais de saúde prisionais possam estabelecer mecanismos de vigilância e inovação das ações de saúde voltadas à população privada de liberdade, envidando esforços para reduzir os desfechos desfavoráveis da tuberculose.

\section{DESCRITORES}

Saúde Pública; Tuberculose; Resultado do Tratamento; Prisões; Prisioneiros; Revisão Sistemática.

\section{RESUMEN}

Objetivo: analizar los factores asociados al resultado desfavorable del tratamiento de la tuberculosis en individuos privados de libertad. Método: revisión sistemática, realizada en marzo de 2021 en siete bases de datos, sin delimitar periodo de publicación. El proceso de selección de las publicaciones y extracción de los datos fue realizado por dos revisores independientes. Resultados: Se identificaron 1.448 publicaciones y nueve se incluyeron en el estudio. El resultado desfavorable se destacó entre sexo masculino, baja escolaridad, residentes en áreas rurales, mayor tiempo de cárcel, visitas ocasionales, transferencia entre prisiones, individuos sin baciloscopia o con resultado positivo en su diagnóstico, sin baciloscopia de acompañamiento, histórico anterior de tuberculosis, ambas las formas clínicas de la enfermedad, VIH/SIDA, alcoholismo, tabaquismo, bajo peso corporal y tratamiento auto administrado. El abandono del tratamiento tuvo relación entre individuos jóvenes y el óbito, a personas mayores. Conclusión: se espera que los gestores y los profesionales de salud carcelarios puedan establecer mecanismos de vigilancia e innovación de las acciones de salud a la población privada de libertad, con el reto de reducir los resultados desfavorables del tratamiento.

\section{DESCRIPTORES:}

Salud Pública; Tuberculosis; Resultado del Tratamiento; Prisiones; Prisioneros; Revisión Sistemática.

\section{REFERENCES}

1. Sacchi FPC, Praça RM, Tatara MB, Simonsen V, Ferrazoli L, Croda MG, et al. Prisons as reservoir for community transmission of tuberculosis, Brazil. Emerg Infect Dis. 2015;21(3):452-5. DOI: http://dx.doi.org/10.3201/eid2103.140896.

2. Soares Filho MM, Bueno PMMG. Demografia, vulnerabilidades e direito à saúde da população prisional brasileira. Ciênc Saúde Coletiva. 2016;21(7):1999-2010. DOI: http://dx.doi.org/10.1590/1413-81232015217.24102015.

3. BRASIL Ministério da Saúde, Secretaria de Vigilância em Saúde, Departamento de Vigilância das Doenças Transmissíveis. Manual de Recomendações para o Controle da Tuberculose no Brasil. 2a ed. Brasília: DF; 2019 [cited 2020 Apr 22]. Available from: https://bvsms. saude.gov.br/bvs/publicacoes/manual_recomendacoes_controle_tuberculose_brasil_2_ed.pdf.

4. Moreira TR, Lemos AC, Colodette RM, Gomes AP, Batista RS. Prevalence of tuberculosis in incarcerated populations: systematic review and meta-analysis. Rev Panam Salud Publica. 2019;43(10):e162019. DOI: https://doi.org/10.26633/RPSP.2019.16.

5. Macedo LR, Maciel ELN, Struchiner CJ. Tuberculosis en la población privada de libertad de Brasil, 2007-2013. Epidemiol Serv Saúde. 2017;26(4):783-94. DOI: http://dx.doi.org/10.5123/s1679-49742017000400010. 
6. Henostroza G, Topp SM, Hatwiinda S, Maggard KR, Phiri W, Harris JB, et al. The high burden of tuberculosis (TB) and Human Immunodeficiency Virus (HIV) in a large Zambian Prison: a public health alert. PLOS ONE. 2013;8(8):e67338. DOI: https://doi.org/10.1371/journal.pone.0067338.

7. Semaille C, Le Strat Y, Chiron E, Chemlal K, Valantin MA, Serre P, et al. Prevalence of Human Immunodeficiency Virus and Hepatitis C Virus among French prison inmates in 2010: a challenge for public health policy. Euro Surveill. 2013;18(28):20524.

8. World Health Organization. The End Tb Strategy. World Health Assembly. Geneva: World Health Organization. 2018 [cited 2020 Mar 22]. Available from: https://www.who.int/tb/End_TB_brochure.pdf?ua=1.

9. Brasil. Ministério da Saúde. Portaria Interministerial n. 1, 2 de janeiro de 2014. Institui a Política Nacional de Atenção Integral à Saúde das Pessoas Privadas de Liberdade no Sistema Prisional (PNAISP) no âmbito do Sistema Único de Saúde (SUS). Diário Oficial da União, Brasília: DF, 2014 [cited 2020 Aug 28]. Available from: http://bvsms.saude.gov.br/bvs/saudelegis/gm/2014/pri0001_02_01_2014.html.

10. Mendes EV. A construção social da atenção primária à saúde. 1 ed. Brasília: Conselho Nacional de Secretários de Saúde - CONASS; 2015.

11. Silva BN, Temoteo RCA, Véras GCB, Silva CRDV. Predisposing factors of tuberculosis in liberty-deprived: an integrative review. Arch Health Sci. 2019;26(1):67-71. DOI: http://dx.doi.org/10.17696/2318-3691.26.1.2019.1051.

12. Valença MS, Cezar-Vaz MR, Brum CB, Silva PEAD. The process of detection and treatment of cases of tuberculosis in a prison. Ciênc Saúde Colet. 2016;21(7):2111-2. DOI: https://doi.org/10.1590/1413-81232015217.13822015.

13. World Health Organization. Draft global strategy and targets for tuberculosis prevention, care and control after 2015: Report by the secretariat. World Health Assembly. Geneva: World Health Organization. 2014 [cited 2020 Mar 22]. Available from: https://apps.who. int/iris/bitstream/handle/10665/152555/A67_11-en.pdf?sequence=1 \&isAllowed=y.

14. Moher D, Liberati A, Tetzlaff J, Altman DG, PRISMA Group. Preferred reporting items for systematic reviews and meta-analyses: the PRISMA statement. PLoS Med. 2008;6(7):e1000097. DOI: http://dx.doi.org/10.1371/journal.pmed.1000097.

15. Donato H, Donato M. Etapas na condução de uma revisão sistemática. Acta Med Port. 2019;32(3):227-35. DOI: https://doi.org/10.20344/ amp.11923.

16. Moola S, Munn Z, Sears K, Sfetcu R, Currie M, Lisy K, et al. Conducting systematic reviews of association (etiology): the Joanna Briggs Institute's approach. Int J Evid Based Healthc. 2015;13(3):163-9. DOI: https://doi.org/10.1097/xeb.0000000000000064.

17. Ouzzani M, Hammady H, Fedorowicz Z, Elmagarmid A. Rayyan - a web and mobile app for systematic reviews. Syst Revi. 2016;5(1):210. DOI: http://dx.doi.org/10.1186/s13643-016-0384-4.

18. Ursi ES, Galvão CM. Prevenção de lesões de pele no perioperatório: revisão integrativa da literatura. Rev Latino-Am Enfermagem. 2006;14(1):124-31. DOI: http://dx.doi.org/10.1590/S0104-11692006000100017.

19. Moola S, Munn Z, Tufanaru C, Aromataris E, Sears K, Sfetcu R, et al. Chapter 7: Systematic reviews of etiology and risk. In: Aromataris E, Munn Z, editors. JBI Manual for Evidence Synthesis. Adelaide: The Joanna Briggs Institute; 2020. DOI: https://doi.org/10.46658/JBIMES-20-08.

20. Alves KKAF, Borralho LM, Araújo AJ, Bernardino IM, Figueiredo RMRM. Factors associated with recovery and the abandonment of tuberculosis treatment in the incarcerated population. Rev Bras Epidemiol. 2020;23:e200079. DOI: https://doi.org/10.1590/1980-549720200079.

21. Mandizvidza A, Dlodlo RA, Chinnakali P, Mugauri HD, Dube F, Gaka E, et al. Tuberculosis Case Finding Cascade and Treatment Outcomes among Male Inmates in Two Prisons in Zimbabwe. Tuberc Res Treat. 2020;2020:5829471. DOI: https://doi.org/10.1155/2020/5829471.

22. Chong F, Marín D, Pérez F. Baja captación y éxito en el tratamiento para la tuberculosis en una cárcel de Ecuador. Rev Panam Salud Publica. 2019;43:e106. DOI: https://doi.org/10.26633/rpsp.2019.106.

23. Khan AH, Sulaiman SAS, Muttalif ARA, Hassali MAA, Aftab RA, Khan TM. Incidence and risk factors associated with tuberculosis treatment outcomes among prisoners. Infect Dis Clin Pract. 2019;27(3):148-54. DOI: http://dx.doi.org/10.1097/IPC.0000000000000719.

24. Adane K, Spigt M, Dinant G. Tuberculosis treatment outcome and predictors in northern Ethiopian prisons: a five-year retrospective analysis. BMC Pulmonary Medicine. 2018;18(1):37. DOI: https://doi.org/10.1186/s12890-018-0600-1.

25. Berihun YA, Nguse TM, Gebretekle GB. Prevalence of tuberculosis and treatment outcomes of patients with tuberculosis among inmates in Debrebirhan prison, north Shoa Ethiopia. Ethiop J Health Sci. 2018;28(03):347-54. DOI: http://dx.doi.org/10.4314/ejhs.v28i3.13.

26. Schwitters A, Kaggwa M, Omiel P, Nagadya G, Kisa N, Dalal S. Tuberculosis incidence and treatment completion among Ugandan prison inmates. Int J Tuberc Lung Dis. 2014;18(7):781-6. DOI: https://dx.doi.org/10.5588/ijtld.13.0934.

27. Macedo LR, Reis-Santos B, Riley LW, Maciel EL. Treatment outcomes of tuberculosis patients in Brazilian prisons: a polytomous regression analysis. Int J Tuberc Lung Dis. 2013;17(11):1427-34. DOI: http://dx.doi.org/10.5588/ijtld.12.0918.

28. Mnisi T, Tumbo J, Govender I. Factors associated with pulmonary tuberculosis outcomes among inmates in Potchefstroom prison in north west province. South Afr J Epidemiol Infect. 2013;28(02):96-101. DOI: https://doi.org/10.1080/10158782.2013.11441526.

29. Ghavidel N, Mahmoodi Z, Sharifipour Z, Harandi TF. Factors affecting self-management in Iranian tuberculosis patients: a path analysis model. Research Square 2021. Preprint. DOI: https://dx.doi.org/10.21203/rs.2.9190/v1.

30. Yew WW, Yoshiyama T, Leung CC, Chan DP. Epidemiological, clinical and mechanistic perspectives of tuberculosis in older people. Respirology. 2018;23(6):567-75. DOI: https://doi.org/10.1111/resp.13303

31. Sánchez AR, Camacho LAB, Diuana V, Larouzé B. Tuberculosis in prisons: an avoidable calamity? Cad Saúde Pública 2006;22(12):2510. DOI: https://doi.org/10.1590/S0102-311X2006001200001.

32. Lemos AP, Ribeiro C, Fernandes J, Bernardes K, Fernandes R. Men's health: the reasons for men to reach out to health services. Rev Enferm UFPE on line 2017;11(Suppl.11):4546-52. DOI: https://doi.org/10.5205/1981-8963-v11i11a231205p4645-4652-2017.

33. Rodrigues MW, Mello AGNC. Tuberculose e escolaridade: uma revisão da literatura. Revista Internacional de Apoyo a la Inclusión, Logopedia, Sociedad y Multiculturalidad 2018;4(2):1-12.

34. Jadgal Khair M, Nakhaei-Moghadam T, Alizadeh-Seiouki H, Zareban I, Sharifi-Rad J. Impact of Educational Intervention on Patients Behavior with Smear-positive Pulmonary Tuberculosis: A Study Using the Health Belief Model. Mater Sociomed. 2015;27(4):229-33. DOI: https://doi.org/10.5455/msm.2015.27.229-233. 
35. Santos JN, Sales CMM, Prado TN, Maciel EL. Factors associated with cure when treating tuberculosis in the state of Rio de Janeiro, Brazil, 2011-2014. Epidemiol Serv Saúde 2018;27(3):e2017464. DOI: https://doi.org/10.5123/s1679-49742018000300015.

36. Watermeyer J, Penn C. Community perspectives on tuberculosis care in rural South Africa. Health Soc Care Community. 2019;27(1): 182-90. DOI: https://doi.org/10.1111/hsc.12637.

37. Ferreira KR, Orlandi GM, Silva TC, Bertolozzi MR, França FOS, Bender A. Representations on adherence to the treatment of MultidrugResistant Tuberculosis. Rev Esc Enferm USP. 2018;52:e03412. DOI: http://dx.doi.org/10.1590/S1980-220X2018010303412.

38. Chikovani I, Diaconu K, Duric P, Sulaberidze L, Uchaneishvili M, Mohammed NI, et al. Addressing challenges in tuberculosis adherence via performance-based payments for integrated case management: protocol for a cluster randomized controlled trial in Georgia. Trials. 2019;20(1):536. DOI: http://dx.doi.org/10.1186/s13063-019-3621-z.

39. Teixeira PA, Jordan AO, Zaller N, Shah D, Venters H. Health outcomes for HIV-infected persons released from the New York city jail system with a transitional care-coordination plan. Am J Public Health. 2015;105(2):351-357. DOI: https://doi.org/10.2105/ajph.2014.302234.

40. Franke MF, Appleton SC, Bayona J, Arteaga F, Palacios E, Llaro K, et al. Risk factors and mortality associated with default from multidrugresistant tuberculosis treatment. Clin Infect Dis. 2008;46(12):1844-51. DOI: https://doi.org/10.1086/588292.

41. Ilgazli A, Boyaci H, Basyigit I, Yildiz F. Extrapulmonary tuberculosis: clinical and epidemiologic spectrum of 636 cases. Arch Med Res. 2004;35(5):435-41. DOI: https://doi.org/10.1016/j.arcmed.2004.05.008.

42. Alves KKAF, Borralho LM, Araújo AJ, Bernardino IM, Figueiredo TMRM. Factors associated with recovery and the abandonment os tuberculosis treatment in incarcerated population. Rev Bras Epidemiol. 2020;23:e200079. DOI: https://doi.org/10.1590/1980-549720200079.

43. Souza ACSV, D’Albuquerque ACC, Araújo RA, Oliveira SF, Carvalho CGN. Características clínico-epidemiológicas da coinfecção por tuberculose e HIV no Estado do Piauí, Brasil. RSD. 2020;9(9):e512997415. DOI: http://dx.doi.org/10.33448/rsd-v9i9.7415.

44. Ferreira MR, Bonfim RO, Siqueira TC, Andrade RLP, Monroe AA, Villa TC, et al. Tuberculosis in prison and aspects associated with the diagnosis site. J Infect Dev Ctries. 2019;13(11):968-77. DOI: https://doi.org/10.3855/jidc.11522.

45. Getahun B, Ameni G, Biadgilign S, Medhin G. Mortality and associated risk factors in a cohort of tuberculosis patients treated under DOTS programme in Addis Ababa, Ethiopia. BMC Infect Dis. 2011;11(1):127. DOI: http://dx.doi.org/10.1186/1471-2334-11-127.

46. World Health Organization. Guideline: nutritional care and support for patients with tuberculosis [Internet]. Geneva: World Health Organization. 2013 [cited 2020 Mar 22]. Available from: https://apps.who.int/iris/bitstream/handle/10665/94836/9789241506410_eng. pdf? sequence $=1$.

47. Moges B, Amare B, Asfaw F, Tesfaye W, Tiruneh M, Belyhun Y et al. Prevalence of smear positive pulmonar tuberculosis among prisoners in North Gondar Zone Prison, northwest Ethiopia. BMC Infect Dis. 2012;12:352. DOI: https://dx.doi.org/10.1186\%2F1471-2334-12-352.

48. Paião DSG, Lemos EF, Carbone ASS, Sgarbi RVE, Junior AL, Silva FM, et al. Impact of mass-screening on tuberculosis incidence in a prospective cohort of Brazilian prisoners. BMC Infect Dis. 2016;16(1):533. DOI: https://doi.org/10.1186/s12879-016-1868-5.

49. Scholze AR, Campoy LT, Arcoverde MAM, Alves JD, Fuentealba-Torres M, Arcêncio RA. Association of smoking with tuberculosis and its negative outcomes: a systematic review. Advances in Nursing and Health. 2019;1:113-26. DOI: http://dx.doi.org/10.5433/anh.2019v1.id38425.

50. Altet N, Latorre I, Jiménez-Fuentes MÁ, Maldonado J, Molina I, González-Díaz Y, et al. Assessment of the influence of direct tobacco smoke on infection and active TB management. PLoS One. 2017;12(8):e0182998. DOI: https://doi.org/10.1371/journal.pone.0182998

51. Cezar CM, Loredo C, Silva JRL, Conde MB. Impact of smoking on sputum culture conversion and pulmonary tuberculosis treatment outcomes in Brazil: a retrospective cohort study. J Bras. Pneumol. 2018;44(2):99-105. DOI: https://doi.org/10.1590/s1806-37562017000000161.

52. Ragan EJ, Kleinman MB, Sweigart B, Gnatienko N, Parry CD, Horsburgh CR, et al. The impact of alcohol use on tuberculosis treatment outcomes: a systematic review and meta-analysis. Int J Tuberc Lung Dis. 2020;24(1):73-82. DOI: http://dx.doi.org/10.5588/ijtld.19.0080.

53. Balabanova Y, Drobniewski F, Fedorin I, Coker R. The directly observed therapy short-course (DOTS) strategy in Samara Oblast, Russian Federation. Respir Res. 2006;7(1):44. DOI: http://dx.doi.org/10.1186/1465-9921-7-44.

54. Dara M, Acosta CD, Melchers NVV, Al-Darraji HA, Chorgoliani D, Reyes H, et al. Tuberculosis control in prisons: current situation and research gaps. Int J Infect Dis. 2015;32:111-7. DOI: http://dx.doi.org/10.1016/j.ijid.2014.12.029.

55. Sánchez A, Leal MC, Larouzé B. The reality of health in prisons and the challenges involved. Ciênc Saúde Coletiva. 2016;21(7):1996. DOI: https://doi.org/10.1590/1413-81232015217.08682016.

56. Cadamuro ACGA, Andrade RLP, Lopes LM, Neves LAS, Catoia EA, Monroe AA. Coordenação do cuidado às pessoas que vivem com HIV no sistema prisional. Acta Paul Enferm. 2020;33:eAPE20190267. DOI: http://dx.doi.org/10.37689/acta-ape/2020AO02676.

57. Martins ELC, Martins LG, Silveira AM, Melo EM. O contraditório direito à saúde de pessoas em privação de liberdade: o caso de uma unidade prisional de Minas Gerais. Saúde Soc. 2014; 23(4):1222-34. DOI: https://doi.org/10.1590/S0104-12902014000400009.

58. Graça BC, Mariano MM, Gusmão MAJX, Cabral JF, Nascimento VF, Gleriano JS, et al. Difficulties of women deprived of liberty in accessing health services. Rev Bras Promoç Saúde. 2018;21(2):1-9. DOI: http://dx.doi.org/10.5020/18061230.2018.7374.

\section{Financial support}

This study was financed in part by the Coordenação de Aperfeiçoamento de Pessoal de Nível

Superior - Brasil (CAPES) - Finance Code 001, and by the Conselho Nacional de Desenvolvimento

Científico e Tecnológico (CNPq) - Research productivity fellowship - process 304517/2018-6. 